Int. J. Environ. Sci. Tech.

(C) Spring 2006, Vol. 3, No. 2, pp. 147-152

\title{
Pollution of south of Tehran ground waters with heavy metals
}

\author{
${ }^{1 *}$ R. Salmasi and ${ }^{2}$ A. Tavassoli \\ ${ }^{1}$ Reserch Center of Agriculture and Natural Resources of East Azarbayjan, Tabriz, Iran \\ ${ }^{2}$ College of Agriculture, Islamic Azad Univrsity, Karaj, Iran
}

Received 17 November 2005;

revised 5 February 2006;

accepted 3 March 2006;

available online 20 April 2006

\begin{abstract}
The reuse of nutrients and organic matter in wastewater sludge via on agricultural lands application is a desirable goal. However, trace or heavy metals present in sludge pose the risk of human or phytotoxicity from land application. The aim of this research is possibility of ground water pollution of south of Tehran because of ten years irrigation with $\mathrm{Ni}$, $\mathrm{Cd}$ and $\mathrm{Pb}$ borne waste water. For this purpose, 6 soil samples from southern parts of Tehran city and 2 ones from Zanjan city without lime and organic matter were selected. The soils differed in their texture from sandy to clayey. Each soil sample in duplicate and uniformly packed into PVC columns. Soil samples were irrigated with $\mathrm{Cd}, \mathrm{Pb}$ and $\mathrm{Ni}$-added wastewater. After irrigating, the columns were cut and the soils separated from sectioned pieces and their heavy metal concentrations ( $\mathrm{Pb}, \mathrm{Cd}$ and $\mathrm{Ni}$ ) were measured by atomic absorption spectrophotometer by use of $\mathrm{HNO}_{3} 4 \mathrm{~N}$ solution. Because of high sorption capacity of these elements by soils, these metals were accumulated in surface layer of the soils. Movement in the soils without lime and organic matter were as low as other samples. Ni has had the most accumulation or the least vertical movement, and $\mathrm{Pb}$ the opposite ones.
\end{abstract}

Key words: Ground water, heavy metal, sludge, phytotoxicity

*Corresponding Author, E-mail: raminsalmasi@yahoo.com

\section{INTRODUCTION}

The reuse of nutrients and organic matter in wastewater sludge via application on agricultural lands is a desirable goal. However, trace or heavy metals present in sludge pose the risk of human or phytotoxicity from land application (Richards, 1998). The potential downward mobility sludge-applied trace metals in soil via leaching have been investigated for several decades. Many researches concluded that there is little potential for trace metal mobility via water percolating through the soil profile (Smith, 1996, Emmerich et al. 1982a and 1982b; Williams et al., 1980 and 1984). But with long-term usage of sewage waste, these metals move too rapidly in a particular soil, and can effect on ground water supplies, especially in areas with high water tables. Some factors that reduce the retention and therefore enhance the mobility of these metals include the properties of the metals, soil texture, $\mathrm{pH}$ and competing cations in the soil solution. Dowdy and Volk (1984), in an extensive review of heavy metals movement in sewage sludge-treated soils, concluded that movement most likely occurred where heavy disposal of sewage sludge was made on sandy, acidic and low organic matter soils, receiving high rainfall or irrigation water. Smith (1991) showed evidence of such movement in a sandy soil which treated with sewage sludge with intervals, over a period of 25 years. Kuo et al. (1985) observed that Cd retention was greater in fine-texture soils with high CEC than in coarse textured soils with lower CEC, while McBride (1995) noted that heavy metals retention were most closely associated with metal-organic complexation and soil $\mathrm{pH}$. Investigations by a number of workers on the movement of heavy metals in soils tend to show that metals added to the soils in wastes particularly in sewage sludge, accumulate on or very near to the surface layers of the soils (McBride, 1995). There is little other evidences to suggest that only a very small percentage of sludgeborne metals leach into the ground water if soil $\mathrm{pH}$ is maintained above 6.2 (Sidle and Kardos, 1977 and Candelaria et al., 1995). Anderson and Nielson (1972) observed that after a 12 year disposal of 84 ton/h of sewage sludge to soils, practically all the $\mathrm{Mn}, \mathrm{Zn}, \mathrm{Cu}$, $\mathrm{Pb}$ and $\mathrm{Cd}$ remained in the surface $0-20 \mathrm{~cm}$ of the soil. Hinesly et al. (1972) on the other hand noted that metals had moved down some $15 \mathrm{~cm}$ in soil following a 3 year disposal of 166 tons/h of sewage sludge.

Van Erp and Van Lune (1991), in a 14 year study of sludge amended soil, found that the concentrations of 
$\mathrm{Cd}$ and $\mathrm{Zn}$ in the leachate decreased over time, whereas $\mathrm{Cu}$ and $\mathrm{Pb}$ concentrations increased. Richards et al. (1998), in a field site which received a heavy loading of wastewater sludge, showed that metals (Cd, Ni, Zn and B) in the sludge plot leachate were found at significantly greater concentrations than in the control plot. Their results showed a preferential flow and metal complexation with soluble organics apparently allow leaching of the metals to the subsoil. Camobreco et al. (1996) found similar results in undisturbed soil columns (which preserve preferential flow path). In contrast, conventional packed soil columns immobilized all applied metals, whether or not soluble organics were present. Udom and Mbagwu (2004) after 40 years disposal of sewage waste in a sandy ultisol (Arenic Kandiustult) in south eastern Nigeria observed that $\mathrm{Pb}$ and $\mathrm{Cu}$ contents were high down to the Bt1 horizon indicated their apparent relatively high mobility in this soil. Dorronso et al. (2002) in the study of heavy metals, migration from a pyrite tailing in a carbonate soil, observed that the less mobile elements ( $\mathrm{Pb}, \mathrm{As} \mathrm{Bi}, \mathrm{Sb}$ and $\mathrm{Ti}$ ) concentrated in the uppermost part of the soil layer, with concentration decreasing downward. The more mobile elements (Co, $\mathrm{Zn}, \mathrm{Cd}$ and $\mathrm{Cu}$ ) tended to precipitated where the $\mathrm{pH}$ was basic, toward the bottom of the layer or in the upper part of the underlying soil. The greatest accumulations occurred within the first 6 $\mathrm{mm}$ in overall soil depth and were negligible below 15 $\mathrm{mm}$. In the study of measured of sludge derived trace metals in Nigerian soils (Monday et al., 2001), were concluded that high leaching of $\mathrm{Cu}$ in soil profile was related to $\mathrm{Cu}$ bound to soluble organic compounds (e.g. humic and fulvic acids). They also concluded that high exchangeable and weakly bound fraction of $\mathrm{Zn}$, were responsible to $\mathrm{Zn}$ movement through the soil profile. Because of increasing disposal of urban and industrial waste on agricultural lands, there is a need to study and understand further the situation of the retention of heavy metals in soil, especially those which are of particular concern because of their relations with certain human health problems. Sewage wastes from different parts of Tehran city transfer to south areas of this city by 2 small rivers. Water deficiency at this area is one reason to use wastewaters to irrigate about 6900 ha of these agricultural lands. Because of sludge-borne metals, and vertical movement to ground water of these waste waters; and high water table in these areas; there is a question that how can we reduce $g$ of wastewater irrigation cause these area's groundwater pollution with heavy metals in long-terms? In other words, how are these elements' movement in the soil profiles with attention to irrigation with wastewater? Answer to these questions is the aim of this study. For this purpose, $\mathrm{Cd}, \mathrm{Ni}$, and $\mathrm{Pb}$ were selected and their movement evaluated in these soils. Location of this research was in southern parts of Tehran city $\left(51^{\circ} 38^{\prime}\right.$ to $51^{\circ} 48^{\prime} \mathrm{N}, 35^{\circ} 14^{\prime}$ to $\left.35^{\circ} 11^{\prime} \mathrm{S}\right)$. This study has been performed in Tehran in 1992.

\section{MATERIALS AND METHODS}

Six regions were selected at the southern parts of Tehran and soil samples were collected from 0-15 cm depths. Selected areas didn't receive sewage waste but they were in adjacent to cultivated lands. To complete different situations of related soil chemistry, 2 soil samples were selected from Zanjan city with same depths which did not have lime and organic matter. The soil samples were air-dried, and passed through a $2 \mathrm{~mm}$ sieve. Different soil properties such as $\mathrm{pH}$, electrical conductivity (EC), cation exchange capacity (CEC), $\mathrm{CaCO}_{3}$ equivalent, gypsum, organic matter, saturated moisture, and texture of the all soil samples were measured in lab (Black, 1965 and Page 1965). The results of physico-chemical properties of soil samples are presented in Table 1 . In this table, soil samples from 1, 2, 3, 4, 5 and 6 are no. of soil samples from south of Tehran city and 7 and 8 are those from Zanjan. As the table shows, the soils differed in their texture from sandy to clayey. The saturation, organic matter and calcium carbonate percentages, $\mathrm{pH}$ and CEC varied from 32 to 73,0 to .83 , and 0 to $20,7.5$ to 8.2 and 7.1 to 35.8, respectively. To irrigate the soil plots, the PVC columns containing soils were prepared as follow:

Each soil sample was duplicate and uniformly packed into $4.6 \times 100 \mathrm{~cm}$ columns. In this study 20 columns were used: Sixteen for soil samples that were irrigated with $\mathrm{Cd}, \mathrm{Pb}$ and Ni added wastewater and 4, for coarsetextured ones that were irrigated with raw wastewater (wastewater without the metals). After irrigation, the columns were cut in different sizes as follow:

Up to $10 \mathrm{~cm}, 1$ to $1 \mathrm{~cm}$.

Up to $20 \mathrm{~cm}, 2$ to $2 \mathrm{~cm}$.

Up to the end of columns, 5 to $5 \mathrm{~cm}$

Then the soils were separated from the cutted pieces and $\mathrm{Cd}, \mathrm{Pb}$, and $\mathrm{Ni}$ concentrations were measured by atomic absorption spectrophotometer (AAS, Perkin Elmer Model 5610) after the samples were digested and extracted in $\mathrm{HNO}_{3} 4 \mathrm{~N}$ solution. 
Pollution of south of...

Table 1: Some of physicochemical properties of the studied soils

\begin{tabular}{|c|c|c|c|c|c|c|c|c|}
\hline $\begin{array}{l}\text { Soil } \\
\text { No. }\end{array}$ & Texture & $\begin{array}{c}\text { Saturated } \\
\text { moisture (\%) }\end{array}$ & $\mathrm{pH}$ & $\mathrm{EC}(\mathrm{ds} / \mathrm{m})$ & $\begin{array}{c}\text { Organic } \\
\text { matter }(\%)\end{array}$ & $\begin{array}{c}\text { Calcium } \\
\text { carbonate (\%) }\end{array}$ & $\begin{array}{c}\mathrm{CEC} \\
\left(\mathrm{Cmol}^{+} / \mathrm{kg}\right) \\
\end{array}$ & Sampling location \\
\hline 1 & Clay & 73.5 & 7.8 & 3.5 & .73 & 20.0 & 16.1 & South of Tehran \\
\hline 2 & Clay & 66.7 & 7.9 & 1.3 & .64 & 15.0 & 35.8 & South of Tehran \\
\hline 3 & Loamy & 51.7 & 7.6 & 3.5 & .83 & 17.0 & 18.4 & South of Tehran \\
\hline 4 & Loamy & 51.4 & 7.9 & 1.3 & .53 & 16.0 & 15.8 & South of Tehran \\
\hline 5 & $\begin{array}{l}\text { Loamy } \\
\text { sand }\end{array}$ & 34.7 & 7.6 & 1.3 & .28 & 12.0 & 7.1 & South of Tehran \\
\hline 6 & Sandy & 31.7 & 8.2 & 2.8 & .26 & 14.0 & 7.9 & South of Tehran \\
\hline 7 & Loamy & 49.5 & 7.5 & 1.0 & .05 & 0.0 & 15.6 & Zanjan \\
\hline 8 & Loamy & 50.3 & 7.5 & .9 & .05 & 0.0 & 16.6 & Zanjan \\
\hline
\end{tabular}

\section{RESULTS}

Movement of $\mathrm{Cd}$, Ni and $\mathrm{Pb}$ through the soil profiles which have lime and organic matter is presented in Figs. 1a, b and c . Figs. 2a, b and c 5 show movement of these elements in soils without lime and organic matter. In Fig. 3, the accumulation of 3 metals within the first 4 $\mathrm{cm}$ of the soils is compared. Also, the accumulation of studied trace metals in soils without lime and organic matter is shown in this Fig. 3. The amount of each element percent in each soil texture group is the mean of 2 soil samples with similar texture.

\section{DISCUSSION AND CONCLUSION}

According to Fig. 1, Cd, $\mathrm{Pb}$ and $\mathrm{Ni}$ accumulated in soil surface layers (in the upper 0 to $2 \mathrm{~cm}$ ), had low vertical movement. These accumulation of these metals in surface layer of the soils, is related to the high sorption capacity of these elements by soil which is a result of chemical reaction between soil solid phases including silicates clays, oxides and hydroxides of metals specially $\mathrm{Fe}$ and $\mathrm{Al}$, amorphous minerals and also lime and organic matter and firm bounds with these components (Corey et al., 1987 and Emmerich et al., 1982). This property accompanying with high rate adsorption of these elements by soil solid phases causes their retention in surface layers of the soils. $\mathrm{Ni}$, $\mathrm{Cd}$ and $\mathrm{Pb}$ penetration in soils is a product of 4 parameters including soil sorption capacity, reaction rate of these elements with solid phase, water movement rate in soil and their primary concentration. Combined effects of these 4 parameters, determine distribution of these metals in soil profiles and depth of movement. As the Fig. 2, (movement of metals in the soils without lime and organic matter) shows, the metals also accumulated in the surface soil layers, and their movement depth were as low as other samples. These results show that other soil components (other than lime and organic matter) also adsorb high quantity of the elements and prevent their penetration to lower depths. These components are: silicates clays, oxides and hydroxides of $\mathrm{Fe}$ and $\mathrm{Al}$ and amorphous minerals. Fig. 3 shows that Ni had the greatest accumulation on the soil surface layer and the least vertical movement, but $\mathrm{Pb}$ had shown the opposite situation except with low difference in the sandy soils. However, accumulation percent within the first $4 \mathrm{~cm}$ of the soils were 70 to 100 percent for different soils and elements. So it might concluded that, because of very low movement of $\mathrm{Ni}, \mathrm{Cd}$ and $\mathrm{Pb}$ in these soils and their accumulation in the first $4 \mathrm{~cm}$ soil depth, it is unlikely happen that the use of wastewater of the southern parts of Tehran affects on the groundwater of these areas with respect to these 3 elements.

However, it did not emphasized on the use of metalspolluted wastewater for irrigation, but it has been clearly shown that pollution of these areas' ground waters by these means is unlikely. 
R. Salmasi and A. Tavassoli

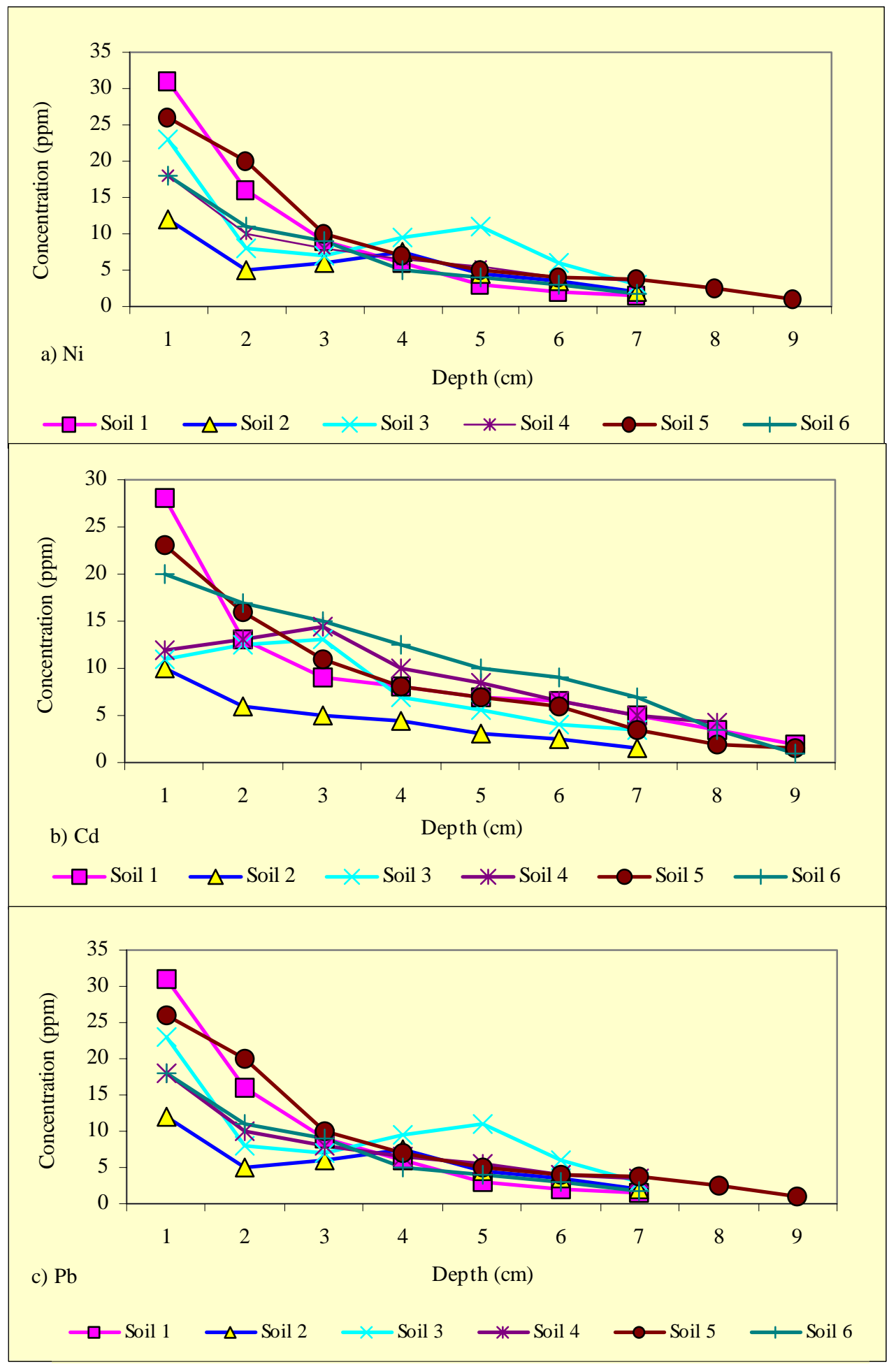

Fig. 1: Movment of a) Ni b) Cd and c) Pb in 1-6 Soils 
It is obvious that it was tried to control the pollution of wastewaters with heavy metals. For this purpose, it is essential to recognize and study the polluted sources of wastewaters. However, if the trend of using wastewater at the southern part of Tehran will continue, because of the health problems, and reduce the risk of groundwater pollution with heavy metals, there is have to be more careful.
Also, it is essential to add lime and organic matter to these soils, especially the coarse-textured ones, set the irrigation periods to be able to prevent soil surface from drying and crusting, prevent deep tillage with soil inversion, using more progressive and effective irrigation methods with low water losses and high water efficiencies.

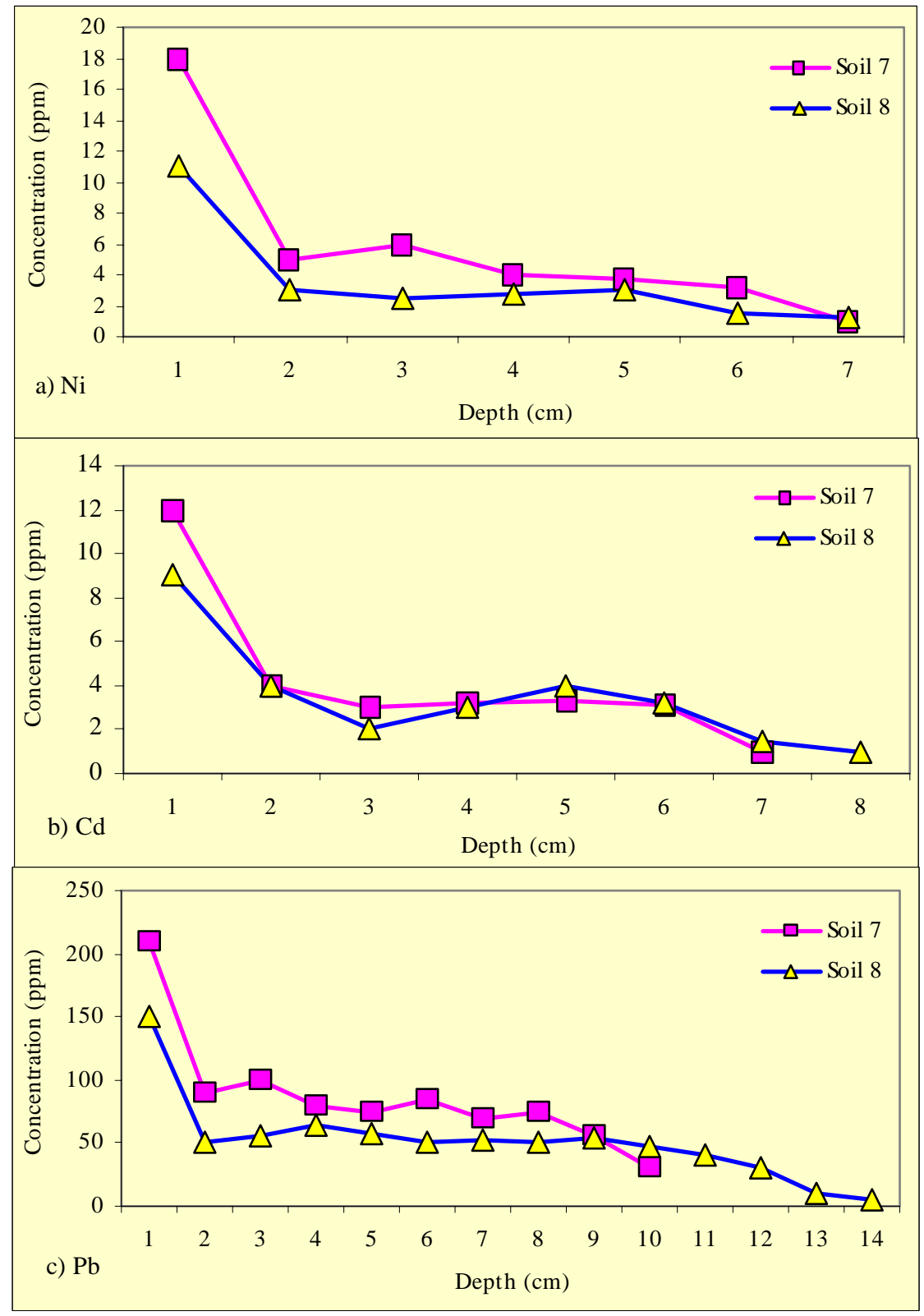

Fig. 1: Movment of a) $\mathrm{Ni}$ b) $\mathrm{Cd}$ and c) $\mathrm{Pb}$ in 7 and 8 soils 


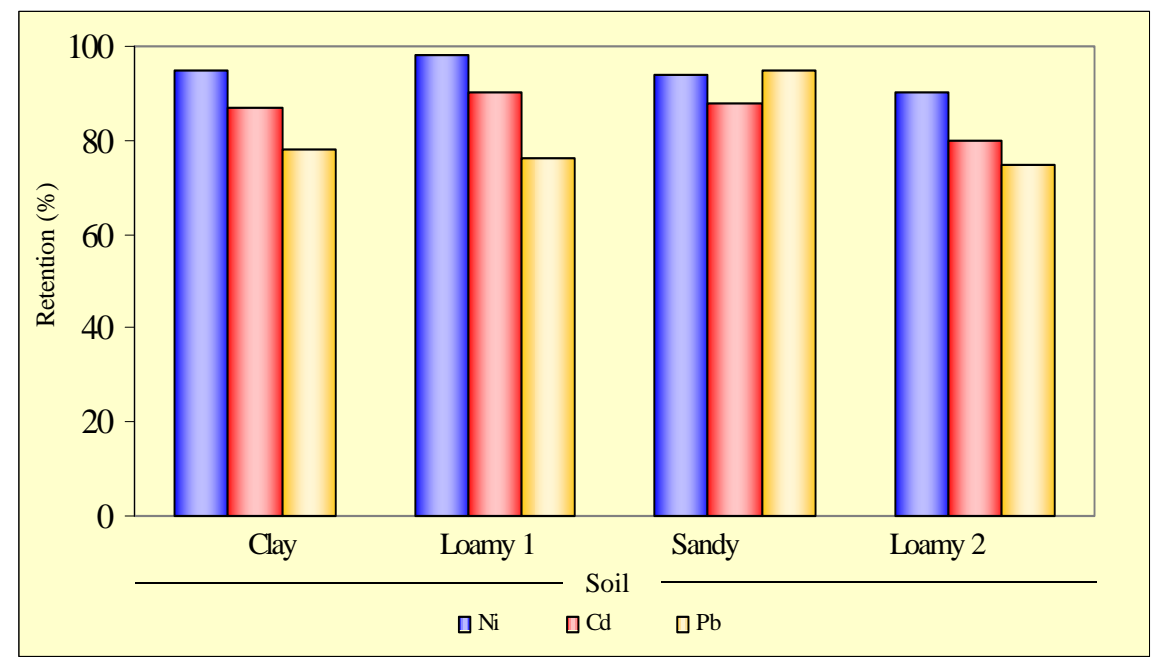

Fig. 3: Ni, Cd and $\mathrm{Pb}$ accumulation percentages in the first fuor $\mathrm{cm}$ of different soils

\section{REFERENCE}

Black, C. A., (1965). Methods of soil analysis, Part 2. $2^{\text {ed. }}$ Ed, Agronomy Monog., ASA, Madison, WI. 9

Corey, J. E., (1987). Metal movement in sludge amended soils, Soil Sci., 143 (2), 124-131.

Dorronsoro, C. and Martin, F., (2002). Migration of trace elements from pyrite tailings in carbonate soils. J. Env. Qual., 31 (1), 829-835.

Emmerich, W. E., Lund, L. J. and Page, A. L., (1982a). Movement of heavy metals in sewage sludge- treated soils. J. Env. Qual., 11, 174-178.

Emmerich, W. E., Lund, L. J. and Page, A. L., (1982b). Solid phase forms of heavy metals in sewage sludge- treated soils. J. Env. Qual., 11 (2), 178-181.

Monday, O. M., Thompson M. L. and Larid, D. A., (2001). Disribution and movement of sludge derived trace metals in selected Nigerian soils. J. Env. Qual., 30 (1). 1667-1674.
Page, A. L., (1965). Methods of soil analysis, Part 1. $2^{\text {ed. }}$ Ed, Agronomy Monog., ASA, Madison, WI. 9

Richards, B. K. and McBride, M. B., (1983). Metal mobility at an old heavily loaded sludge application site. Environ. Poll., 99 (2), 365-377.

Smith, S. R., (1996). Agricultural recycling of sewage sludge and the environment. CAB International, UK.

Udom, B. E. and Mbagwu, J. S. C. (2004). Distribution of Zn, $\mathrm{Cu}, \mathrm{Cd}$, and $\mathrm{Pb}$ in a tropical ultisolsol after long-term disposal of sewage sludge. Environ. Int., 4 (2), 467-470.

Williams, D. E., Vlamis, J., Pukite, A. H. and Corey, J. E., (1980). Trace element accumulation, movement, and distribution in the soil profile from massive applications of sewage sludge. Soil Sci., 129 (3), 119-132.

Williams, D. E., Vlamis, J., Pukite, A. H. and Corey, J. E., (1984). Metal movement in sludge treated soils after six years of sludge addition. Soil Sci., 137 (2), 351-359.

\section{AUTHOR(S) BIOSKETCHES}

Salmasi, R., M.Sc., College of Agriculture, Tehran University, scientific research member of Watershed Section of Research Center of Agriculture and Natural Resources of East Azarbayjan, Tabriz, Iran. E-mail: raminsalmasi@yahoo.com

Tavassoli, A., College of Agriculture, Islamic Azad Univrsity, Karaj, Iran.

E-mail: tavasoli@yahoo.com

\section{This article should be referenced as follows:}

Salmasi, R. and Tavassoli, A., (2006). Pollution of south of Tehran ground waters with heavy metals. Int. J. Environ. Sci. Tech., 3 (2), 147-152. 